\title{
Visions of an Imagined Venice Suspended Between Memories and New Possibilities
}

\author{
Enrico Pietrogrande \\ University of Padua, D.I.C.E.A. \\ Via Marzolo 9, 35131 Padua, Italy \\ enrico.pietrogrande@unipd.it
}

\author{
Alessandro Dalla Caneva \\ University of Padua, D.I.C.E.A. \\ Via Marzolo 9, 35131 Padua, Italy \\ alessandro.dallacaneva@dicea.unipd
}

\author{
Nicola Sartorello \\ University of Padua, D.I.C.E.A. \\ Via Marzolo 9, 35131 Padua, Italy \\ n.sartorello2003@gmail.com
}

This paper investigates the composition of heterogeneous fragments, excerpts from the inventory of collective memory, and the resulting unpredictable architecture in an urban context. The project focuses on the city of Venice, its medieval urban tissue, its Renaissance and Baroque works. The freedom to assemble figures or fragments, to place them in another context, highlighted the effectiveness and decisiveness of a reading of urban design in which the figurative force is the result of consideration based on the visual relationships between objects. The experiences presented outline certain unreal circumstances, but nevertheless inspire a scale evaluation of the results of planned modifications, and suggest corrections, adjustments and new possibilities. The experimental setting, that some may deem fantastical, is derived from the superimposition of an existing environment and works introduced from other contexts. In this way, the artist can redesign and foreshadow, creating a fictional city that can paradoxically serve as a reference in the development of new possible urban settings.

The juxtaposition of well-known architectures to provide form to new spatial connections in the environment verifies new unthought-of opportunities to compose buildings and monuments that modify the space. The inventions resulting from the union of individual architectures into unitary visions that do not organically belong together is a particular iconography in which buildings abandon the passive and ornamental function thanks to which we have got to know them and reacquire an actively elevated role in the project.

A similar procedure that tests the possibility of enhancement of the context and the monument was experimented by the greatest architect of romantic classicism, Karl Friedrich Schinkel, and can be seen in one of his best known designs called Large composition, how Milan Cathedral should be situated (1810). So the monument of the Lombard city is represented on a hill that overlooks a large city on the coast, perhaps Trieste, in order to test a new version of the relationship, here between architecture and nature. It is one of the most well-known anticipated explorations carried out in the past in a planning method facilitating upstream project verification aimed at the evaluation on the one hand of the impact of a new architecture on the environment, and on the other hand, of the opportunity to enhance a given place.

Venice. Imaginary city. Memories. Urban setting.

\section{INTRODUCTION}

In the course of its history, Venice has been frequently subject to invented representations in paintings. Many artists related the medieval architectural fabric with monumental buildings that in turn belonged to a context that existed long ago or to other places that used to exist in the same city. During the baroque period Giovanni Paolo Panini, Giovanni Antonio Canal known as Canaletto, Bernardo Bellotto, Francesco Guardi, Michele Marieschi, Giovanni Battista Piranesi, Hubert Robert, William Marlow and several other artists catalogued as vedutisti turned their attention beyond the real. They painted representations of Italian cities such as Rome and Venice that were syntheses of objective information and imagined components. (Sestieri 2015). For example, among these works of art regarding the city of Venice is the veduta by Canaletto of the four bronze horses from Constantinople framed on tall plinths in front of Palazzo Ducale (Figure 1). We certainly know that this setting, represented in the canvas Caprices: the Horses of San Marco in the Piazzetta, does not correspond to a real-life situation. 


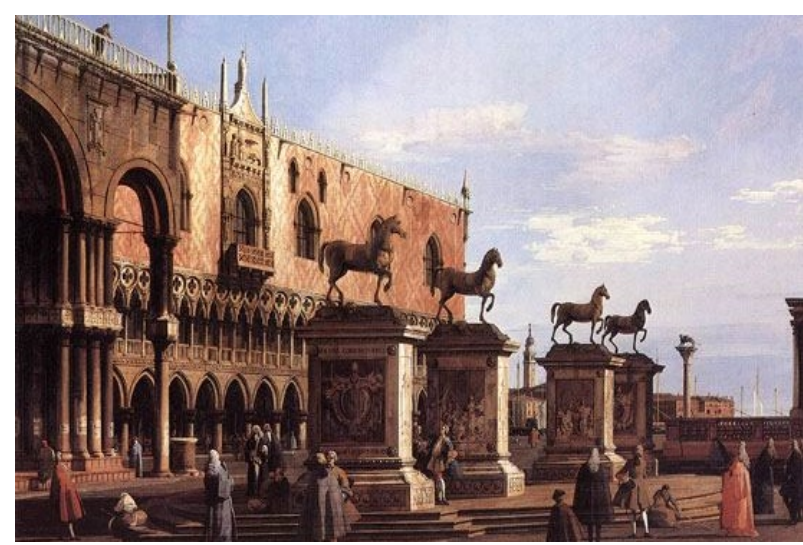

Figure 1: Giovanni Antonio Canal, known as Canaletto, Caprice: the Horses of San Marco in the Piazzetta, 1743. To be noted that the position of the four horses is completely invented.

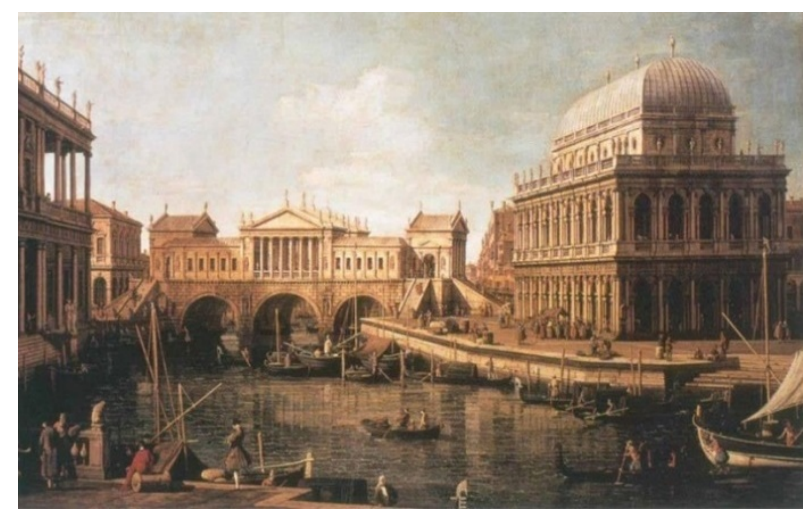

Figure 2: Giovanni Antonio Canal, known as Canaletto, Caprice with buildings by Palladio, 1756-59. The Rialto Bridge here represented was designed by Palladio.

Canaletto was also the author of another famous image of a Venetian space in which place and time do not reflect reality. About the middle of the eighteenth century he painted the canvas Caprice with buildings by Palladio, in which the project of the Rialto Bridge over the Grand Canal developed two centuries beforehand by the architect Andrea Palladio appears. The bridge, that never was built, is painted together with two other buildings by Palladio, Palazzo Chiericati and the Basilica (Figure 2), that are part of Vicenza, another city of the Republic of Venice.

The architect Aldo Rossi (1975) is author of one of the most significant comments about this work of art.

What matters most in this frame is the theoretical construction, the hypotheses of a theory of architectural planning in which the elements are formally prefixed and defined but in which the meaning triggered at the end of the operation is the unexpected but authentic original meaning of the research.

The architectural project in Canaletto's Rialto is compared with the place and inevitably interacts with it by proposing alternatives to the real city.

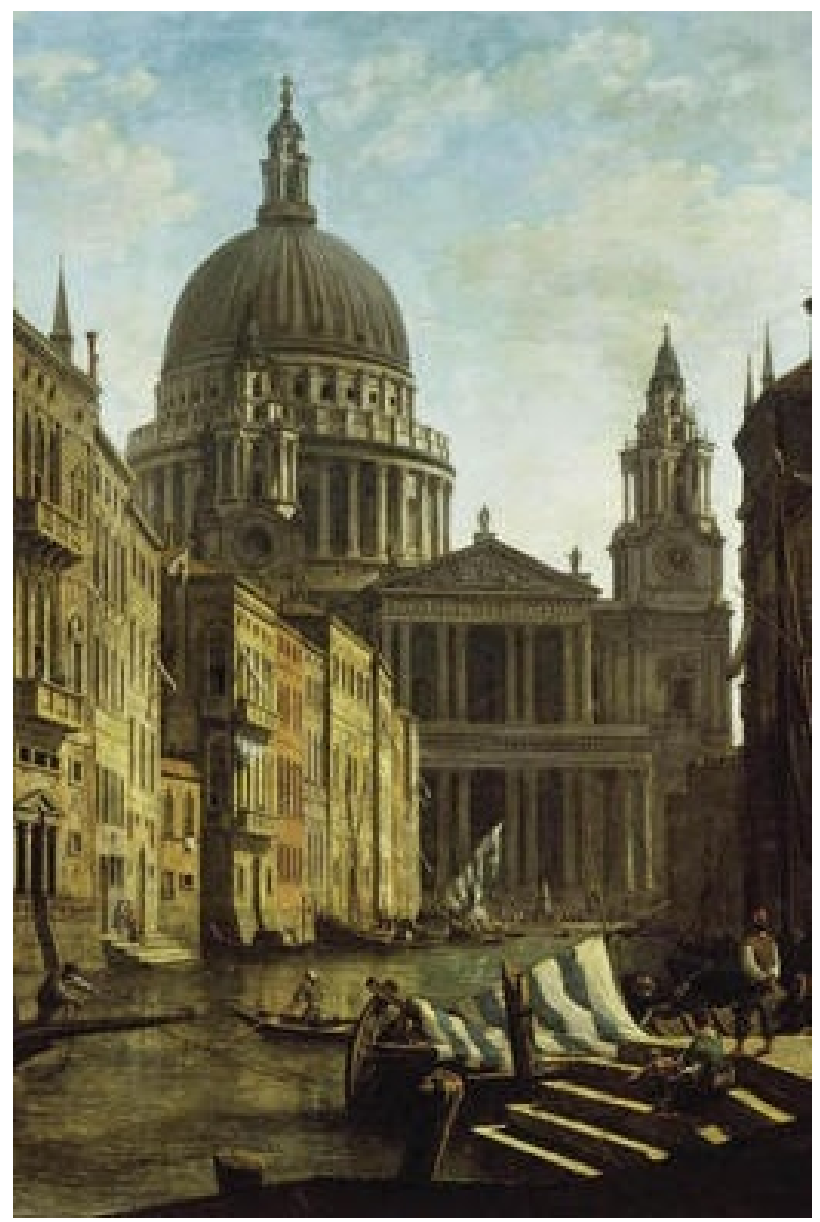

Figure 3: William Marlow, Capriccio: St Paul's and a Venetian Canal, 1795. The cathedral designed by Christopher Wren is painted in Venice.

The bridge, the Basilica, and Palazzo Chiericati are placed in the scene and commented on as if the artist wanted to present a view of an urban context effectively observed by him. In the chosen environment, Canaletto juxtaposes architectures from other places and epochs providing form to new spatial connections, thereby verifying unthought-of opportunities to compose buildings and monuments that modify the space. Through the practice of constructing by using perspective, architectures put into play acquire a new relief that attributes power to both the context enriched with new value and to the individual projects in their renewed conversation and/or interaction with the context.

Returning to the general theme of the vedutisti of the baroque era and given the specific relationships these artists, and Canaletto in particular, had with London, among the pictorial experiments of the time it is also appropriate to mention a painting of St. Paul's Cathedral by William Marlow set as background of a Venetian canal (Figure 3). An imaginary relationship between classicism and a medieval urban fabric is derived again, in the particular case between the London monument and the minor architecture of Venice. 


\section{METHODOLOGY}

The forms are not important as such but the relationships that bind them together are. "More than the things themselves, it is the relationships that cause the things to mean something" (Rossi 2008). So the intention is not to be occupied with the logical-formal structures that regulate the construction of the project, according to a concept of beauty born out of studying the plan/design, the specific place where the idea takes shape. The conclusion sought after is instead a reflection on the interactions between the forms in the space that, according to precise relationships, aim to manifest the life of the forms. In this sense, the beautiful is not investigated by the application of schemas or principles but trusts its own representation to evocation, rhythm, view, movement, with the stated purpose of communicating the meanings and reawakening memories, in order to rediscover in the form the connection between reality and imagination. In other words, the proposal is a reading starting from the forms in the space that highlights the relationships that the imagination through the memory institute between the parts in order to "develop the images the memory has treasured into new relationships" (Quatremère De Quincy 1985).
The architect here considered, freed from been a slave to the use just like a painter, freely arranges, according to specific relationships, objects, and things. This type of architect composes cities of memories as Still Lives or painted architectures (Contessi 1985) made of inert fragments of reality such as towers, churches, town halls, chimneys and schools. Paradoxically, these compositions emptied of the presence of mankind reveal an intense interior life, responding to emotive, symbolic and ideal investments.

It is not by coincidence that the buildings that largely contributed to the formation of the character of the urban landscape belong to the architects who were above all painters before being constructors. Karl Friedrich Schinkel, whose architectural designs defined the face of nineteenth century Berlin, was firstly a painter and a scenographer. After that, he was only thirdly an architect. Hendrik Petrus Berlage, author of the expansion plan for Amsterdam Plan Zuid (South Plan) in addition to various other urban plans in Holland, trained as a painter before embarking on a career as an architect. (Berlage 1934). Le Corbusier, well-known for examples of urban plans, painted on a daily basis. The attitude of composing to represent is the pre-eminent aspect of these authors.

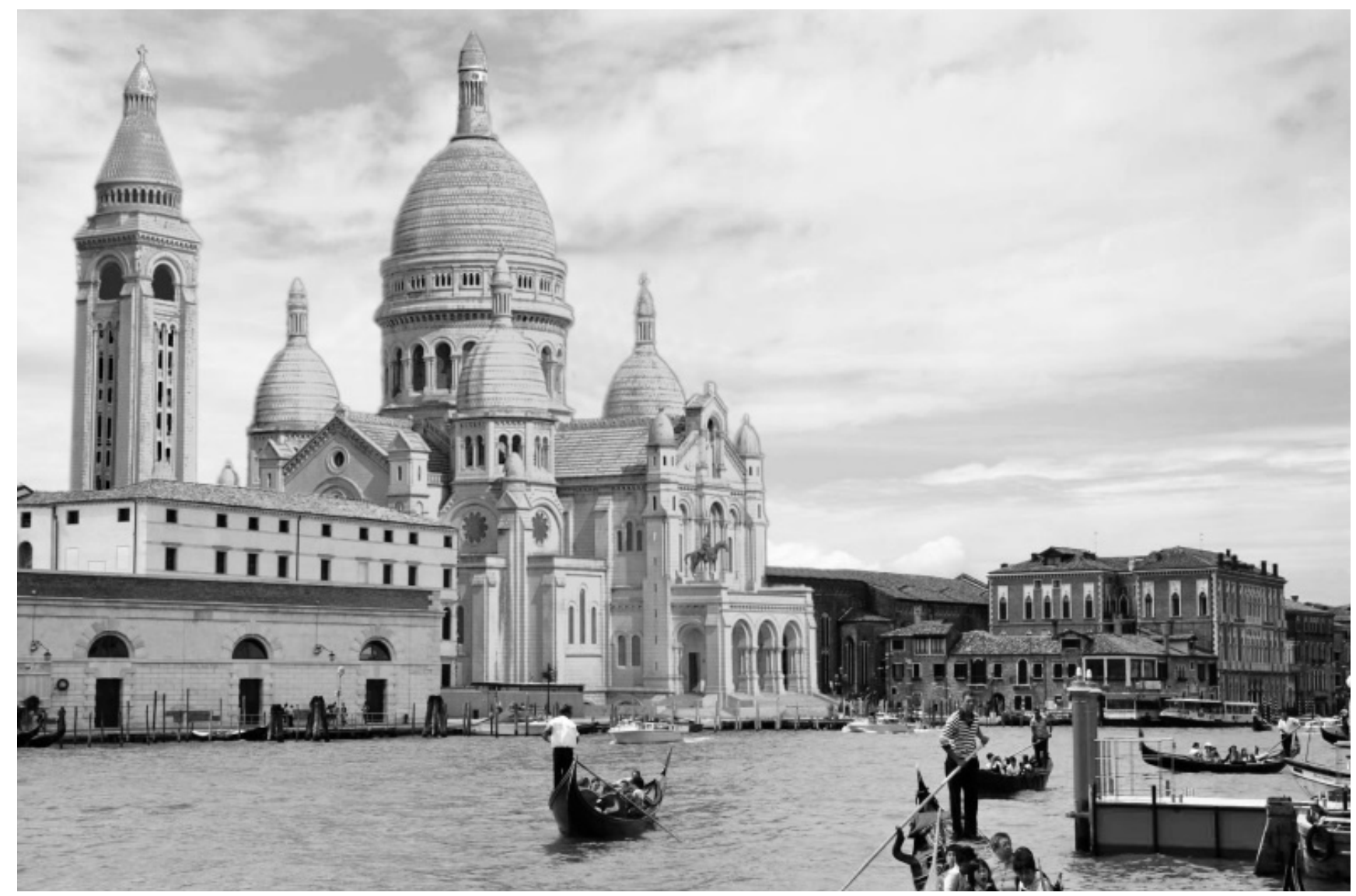

Figure 4: View of the site of the Basilica of Santa Maria della Salute (Basilica of St.Mary of Health) from piazzetta di San Marco substituted by the Parisian Basilica of the Sacré-Cœur (Sacred Heart).. From the work of the students Sarah Reverenna and Enrico Sinato. 


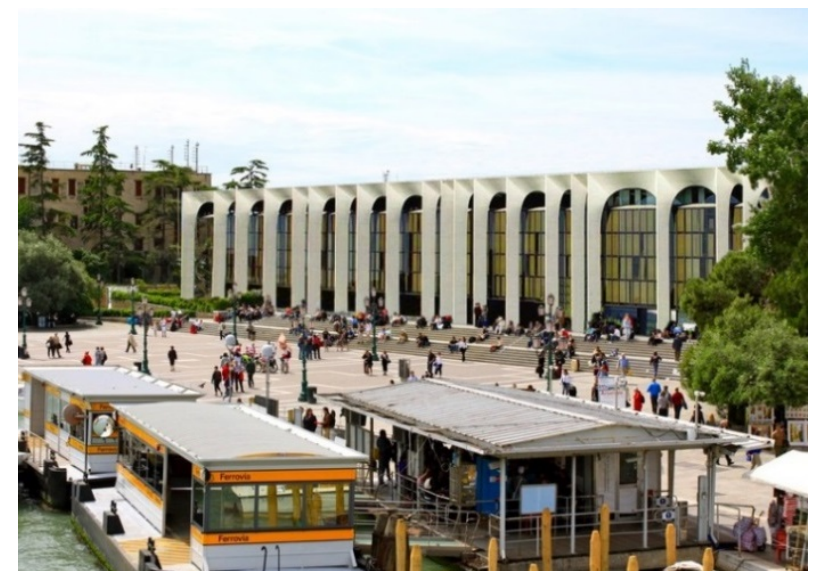

Figure 5: The external appearance of Venice railway station on the Grand Canal in the form of the head office of the publisher Mondadori built at Segrate, near Milan, to the design of the Brazilian architect Oscar Niemeyer (1968-

75). From the work of Sara Coppo and Elisabetta Pendini.

The freedom to assemble fragments or figures, their remounting in a strange context that does not belong to them, without having to confront the urban structure, has emphasised how effective and decisive the reading of the urban project is when the figurative strength is the result of thinking according to the relationships between the objects. These relationships show the ability of the painter, the sculptor, the poet, and the musician to reveal in their compositions that authentic sense of reality that the arts have always pursued without ever seizing it. This feeling emerges from the peace and quiet of a Morandi, from the enigmas of a Böcklin, and from the surreal in a Sironi or De Chirico, where mystery insinuatingly slips between the huge voids and large gaps of a rediscovered architecture and dialogues between mute forms that belong to different worlds seem impossible. The city for the old Masters was built according to aesthetic principles and so they worried about arranging the buildings more evidently in the main places in the city according to determined sizes and proportions. The city is a collective fact and its spaces are the depository of a shared memory due to which the efforts made by the ancients were oriented to manifesting the eternal spirit of the community that those spaces have produced rather than the ephemeral spirit of the architect.

There are many examples in which passages of the city are compositions of rediscovered architecture recomposed in a fresh, innovative, and original way, able to evoke meanings and construct infinite relationships with the city, proposing through the imagination an alternative to the reality. Consequently, architecture can be thought of as a combinatory art whose aim is to bring memories and feelings to light. The task or duty of architecture is to arrange the parts according to measurable relationships capable of producing emotions.

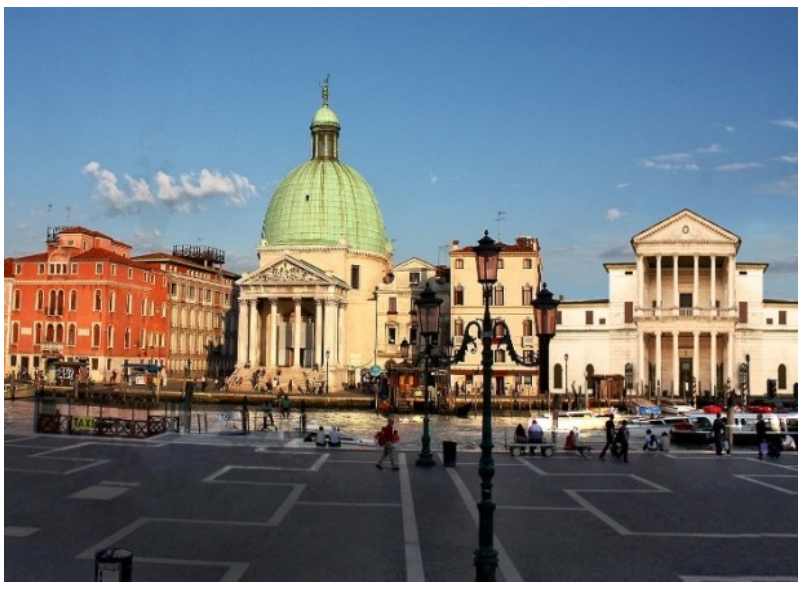

Figure 6: Villa Cornaro to the right, a work of Palladio built in the mid-sixteenth century aligned along the Grand

Canal opposite the railway station and beside the eighteenth-century church of Saints Simon and Jude. From the work of Sara Coppo and Elisabetta Pendini.

According to Le Corbusier (1930), the duty of the architect is to compose the fragments of the reality in describable and measurable relationships able to return the feelings that produced it.

Two or three people observed in a popular tavern drinking coffee and having a chat. The table is still covered with glasses, bottles, plates, the oil cruet, salt, pepper, napkins, and napkin rings, considered the fatal order that places all of these objects in relationship with the others. Each one of them serves for something, they were chosen by the hand of someone or other. The distances separating them are the measure of life. It is a matter of a mathematically assembled composition. No errors, no empty spaces, and no false points are to be found.

It is the size and proportions that made Adolf Loos (1910) recognise the meaning of the tumulus as a place of burial.

If we find a tumulus six feet long and three feet wide in a wood, arranged with the altarpiece in a pyramidal shape, we become serious and something inside us says: someone is buried here. This is architecture.

Several contemporary artists have become experienced in the study of places by varying real elements in it and in the analysis of the imaginary environment deriving from The digital designer Anton Reppon, for example, has produced a series of images in which he simulates new environments for eleven important buildings in New York, masterpieces of contemporary architecture, that are imagined as being isolated in a desolate, inhospitable context, in the desert or on the open sea, becoming unknown and therefore unreachable. The Ukrainian artist Alexey Kondakov has worked on anonymous images of public spaces in the outskirts of the city of Kiev in which figures from other epochs with different attitudes are fitted. 
The Frenchman artist Julien de Casablanca, the Canadian Chris Helgren, the Sicilian Alberto Alicata, the photographer of German origin Julia FullertonBatten who works on the change of scale (Figure 14) are also committed to variations in the context in order to find a relationship between our life environments and the collective culture. The artists shape experimental environments by redesigning places and cities using slippage in time and between places, a shaping that is not real but imagined, and is possible albeit with a little variation.

\section{APPLICATIONS. THE DIDACTIC EXPERIENCE}

The theme above considered was carried out in the laboratory of the Urban and Architecture Composition II course (regular professor Enrico Pietrogrande, co-workers Alessandro Dalla Caneva and Nicola Sartorello, 2015-16 academic year) on the Civil Engineering - Architecture degree course at the University of Padua (Department of Civil, Environmental and Architectural Engineering). Students were required to verify the quality of the public spaces of case studies ancient cities, particularly Venice and Rome, through the characteristics of certain buildings specifically assumed.

The Basilica of Santa Maria della Salute, designed by the architect Baldassare Longhena and consecrated in 1687, is substituted in the view of the Grand Canal in Venice by the nineteenth century Basilica of the Sacré-Cœur built in Paris on the hill of Montmatre to the design of Paul Abadie (Figure 4). The Parisian basilica, whose construction was started in 1875 and completed in 1914 , is characterised by the relief of the travertine covered façades that make it particularly visible.

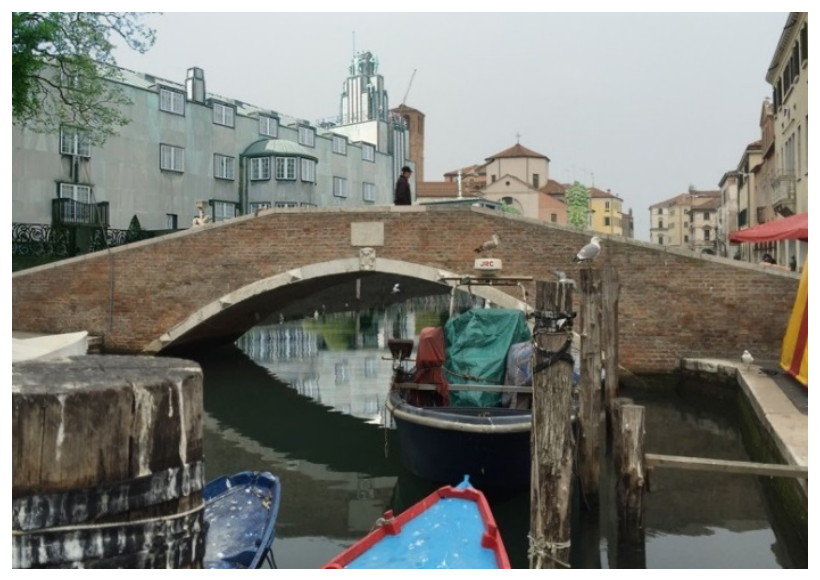

Figure 7: View of the architecture of Palazzo Stoclet built in Bruxelles between 1905 and 1911 to the design of Josef Hoffmann, proposed in the fabric of the minor buildings of the Venetian island of Chioggia. From the work of the students Federico Boscolo Menela and Giada Pozzato.
The Venice railway station building which also faces the Grand Canal is proposed in the form of the head offices of the publisher Mondadori in the Milanese suburb of Segrate built to the design of the Brazilian architect Oscar Niemeyer and inaugurated in 1975 (Figure 5). In place of the existing building, designed by Angiolo Mazzoni and Virginio Vallot between 1936 and 1943 with the subsequent intervention of Paolo Perilli, the sequence of arches that characterises the coherent and monumental work by Oscar Niemeyer was hypothesised. The form of the arch and the method of iteration, constant presences in the city of Venice, attenuate the subversive strength of the large surface areas of glass.

A work by Palladio was simulated in the reverse shot of the opposite bank of the Grand Canal by inserting the architecture of villa Cornaro, built at in the sixteenth century and still in existence (Figure 6 ). The gigantism of the Palladio building comes into comparison with the screen of small buildings that look out onto the canal and with another classicist architecture but built two hundred years later, that is to say, the eighteenth-century church of Saints Simon and Jude, the so called San Simeone Piccolo, which is a work by Giovanni Antonio Scalfarotto. Colonnades and gables undertake a dialogue between different epochs emerging in the shared context of the historic Venetian context. Andrea Palladio only worked in the city of Venice thanks to religious customers, designing and bringing sacred building to fruition.

One of the most famous works of the Viennese Secession art movement, Palazzo Stoclet, reflects in the water the main façade from the bank of the Vena Canal in the historical centre of Chioggia which is built on an island in the Venetian lagoon (Figure 7).

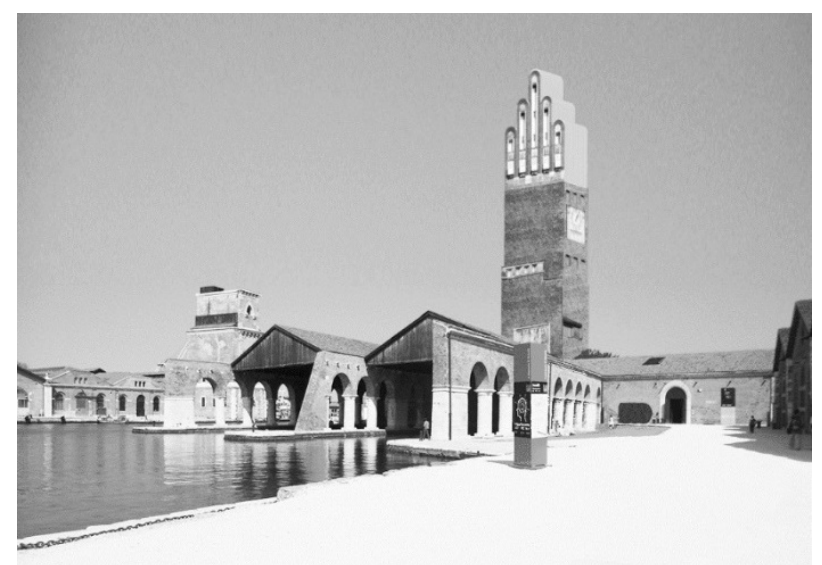

Figure 8: Between the hangars and warehouses of the Venice Arsenal the Hochzeitsturm constitutes a precise vertical sign. The tower was erected at Darmstadt to the design of the architect Joseph Maria Olbrich in 1907. From the work of the students Dario Fantinato and Francesca Guaraldo. 
The building was designed by Josef Hoffmann and built in Brussels in the first decade of the twentieth century. Palazzo Stoclet is inserted in the fabric of the pre-existing history in a non-violent way thanks to its controlled form and the greenish softening of the Norwegian marble and the oxidisation of the metal roofing with the passage of time. As the students Federico Boscolo Menela and Giada Pozzato have observed, the decaying nature that characterises Palazzo Stoclet due to the inexorable passage of time produces the same feeling that is felt in the Venetian Lagoon and particularly in Chioggia, where buildings seem to be very old, left at the mercy of the passing of the years and erosion by atmospheric agents and the salty sea air.

In the Venice Arsenal, which was once the largest industrial establishment the world had ever known, the verification of the relationship between the architectural monuments of the Secession art movement and the Venetian context is repeated. In the place where the Republic of Venice manufactured ships for its fleet, the volumetric expanse of the hangars is dominated by an architecture developed vertically, the Hochzeitsturm designed by Joseph Maria Olbrich for the artists village of Darmstadt in the same period as Palazzo Stoclet (Figure 8). Using the brick common to the architecture of the Arsenal and the tower built by Olbrich sets up a relationship between the hangars stretched over the water and the strong vertical signal of the tower which connects the two historic fields through the centuries that passed between them.

Olbrich also designed in 1897 the Secession Building, which was built in Vienna near the Karlsplatz as a meeting place for the anti-academy artists of the Secession art movement who organised exhibitions of their work there.

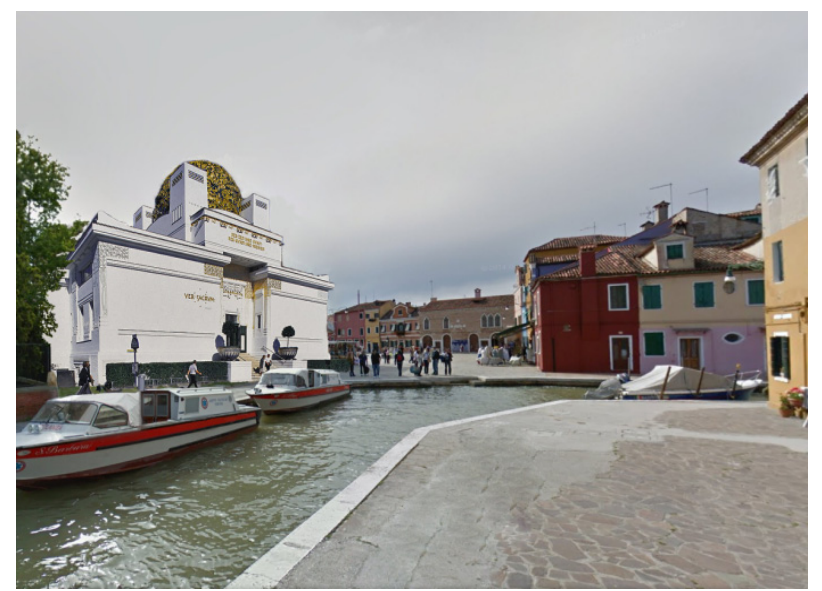

Figure 9: The Secession Building by Joseph Maria Olbrich built in Vienna at the end of the nineteenth century, set here in piazza Galuppi in Burano in the Venice lagoon. . From the work of the students Elisa Castagna and Eri Cavallin.
The Secession building is transferred to Burano, an island in the northern part of the Venetian Lagoon, where it establishes a dialogue with the vivacious colours of the historic minor architecture that characterises the place (Figure 9). The building from Vienna is configured as a sacred place, a temple of art, inserted without contrast thanks to the limited height and modest volume in the environment. It confirms the Mediterranean features that Olbrich had already expressed in the design.

A metaphysic architecture designed by Aldo Rossi with Gianni Braghieri and built in Modena in the 1970s with the function of ossuary of the San Cataldo cemetery substitutes the Basilica di San Marco (St. Marks Basilica) (Figure 10). The cubic construction with the regulated windows is bleak, the use of adjectives to describe it being reduced in contrast to the richness of the finishing that marks the basilica. So the conversation with the built frontages on the piazza is mute because they do not find a reply in the nude prismatic volume which, with no characteristic features of movement, metaphor for the dead in the ideas of the designers, seems to be absent.

The Guggenheim Museum in Bilbao has been thought of as a large sculpture placed in Venice at the crossing of the Grand Canal and the Giudecca Canal (Figure 11). The work of Frank O. Gehry completed in 1997 is an architecture with strong contemporary characteristic features. It substitutes the existing warehouses in the triangular area of the Punta della Dogana and weaves a dialogue with the nearby basilica of Santa Maria della Salute and the Palazzo Ducale. This experimental architecture by Gehry, one of the most effective representations of deconstructivism, is proposed as a giant sculpture on the water characterised by the titanium coating.

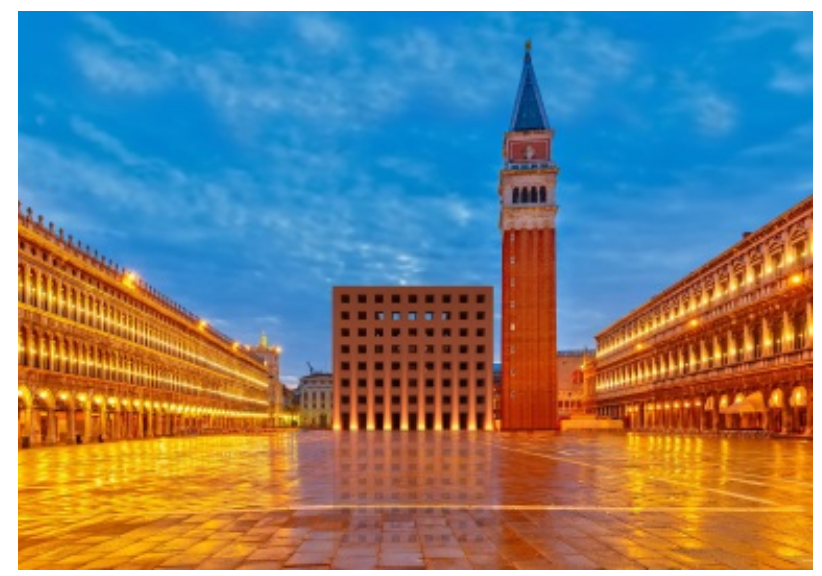

Figure 10: The metaphysical architecture of Aldo Rossi (with Gianni Braghieri) built in Modena as an ossuary that substitutes the basilica di San Marco (St. Marks

Basilica) in Venice alongside palazzo Ducale.. From the work of the students Enrico Palladin e Marco Ragagnin. 


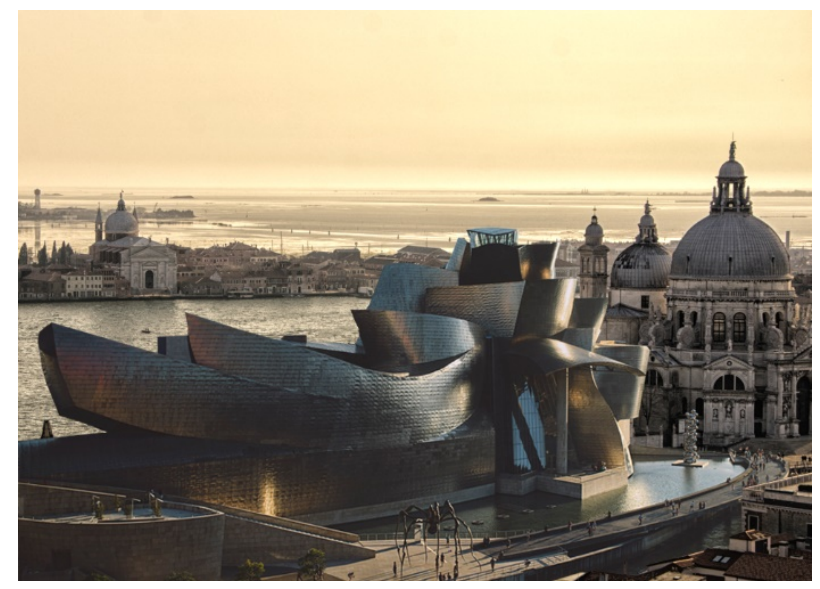

Figure 11: The Guggenheim Museum in Bilbao, inaugurated in 1997 to the design by Frank O. Gehry, hypothesised at the Punta della Dogana between the Grand Canal and the Giudecca Canal. From the work of the students Valeria Lanciai and Milica Mitrovic.

The titanium coats a large part of its external surfaces just like lead protects the rooves of the nearby monuments. The new technology interprets organic forms, and perhaps this is why it does not give rise to a perpendicular relationship with the millennial Venetian environment.

A building covered in sandstone is proposed for Campo Manin, through which the architect Rafael Moneo has given form to the enlarged town hall of Murcia completed in 1998 (Figure 12). Another contemporary building really presses on the same public space. This is the former head office of the Venice Savings Bank completed in 1970, designed by the engineer Pierluigi Nervi and architect Angelo Scattolin. A complex relationship has been established in the square named Campo Manin between historic buildings, the interpretation that Moneo gives to historic architecture and the attempt by Nervi and Scattolin to dialogue with the historical spirit of the place.

\section{RESULTS}

The composition of a consolidated historical context such as that of Venice and of the minor centres around its lagoon with architectural models coming from the infinite building heritage available in the built world has made it possible to evaluate several things. Leaving the example of the nonreligious works of Palladio aside which has his own reasons for the total lack of lay buildings by Palladio in Venice, the other eight architectures proposed are distinguished by being contemporary or belonging to the beginning of the last century. In both cases it was possible verify the relationship between old urban fabric and recent works, between old and new, between precious consolidated architectural heritage and new building contributions.

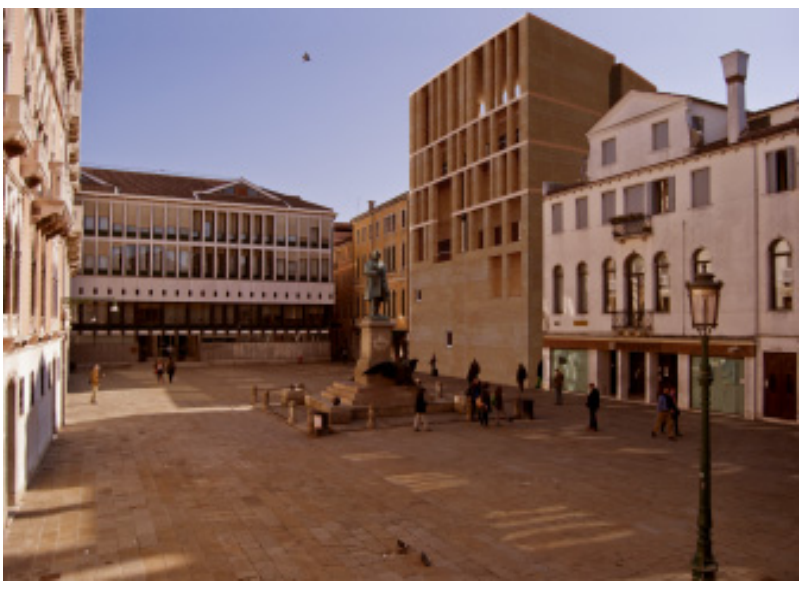

Figure 12: Campo Manin modified by the presence of a work by the Spanish architect Rafael Maneo on the right of the image, that is, the extension of the town hall in Murcia. From the work of the students Andrea Basso and Laura Lazzarini.

With reference to the projects of Hoffmann and Olbrich, and to the Parisian cathedral of Paul Abadie, the easy integration emerges with the historic fabric of Venetian building. This almost induces the recognition of a specific affinity of the architecture of the Secession art movement with the minor buildings of the island, perhaps deriving from the links that have held Vienna and Venice together in a close relationship during the many years that have passed since Napoleonic times. On the other hand, the anti-academic motivation of the Secession favoured an architectural lexicon that is not bound by stylistic rules.

The compositions obtained by putting well-known examples of the architectural production of our years into play have revealed or confirmed the importance of the agreement with the context of the volumetric dimension, the finishing materials, and the forms implemented. This has resulted in the austere incidence in the context of a minimal architecture like that of Aldo Rossi, which arranged on the piazza San Marco imposes its cold, and aseptic presence based on the purity of the geometry in one space already governed by the rules of elementary geometry to start from the prism of the bell tower. The relationship of the building designed by Moneo with the architecture persisting on the Campo Manin is smooth, favoured by the dialogue of the sandstone that covers it with the local materials. The organic form produced by Gehry in the deconstructive Guggenheim Museum is comparable to an urban-scale sculpture, isolated on the Punta della Dogana, relating positively to an environment in which nature still dominates.

However, it is clear that it is better to create a significant contrast rather than a false imitation. Consequently, the insertion of recent works in this experience has guaranteed basic respect of the parts that characterise the context. 


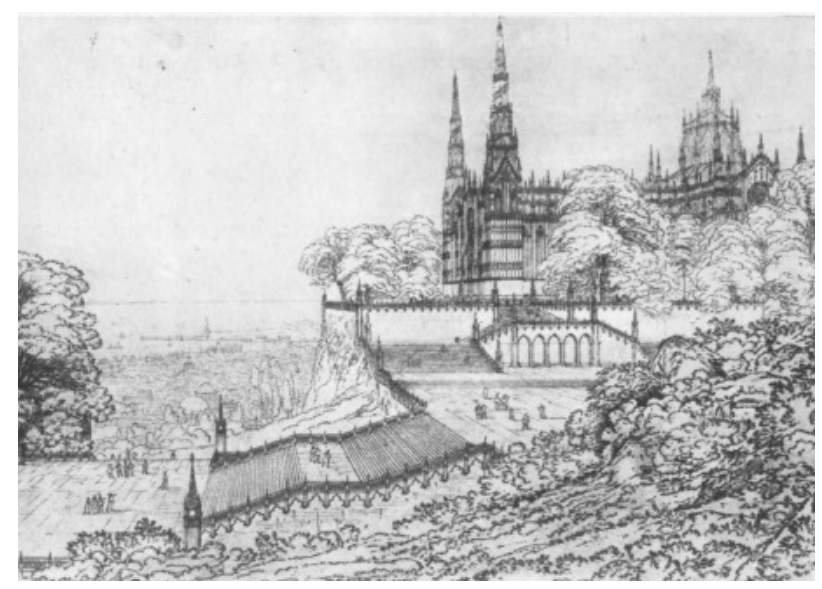

Figura 13. Karl Friedrich Schinkel, Large composition, how Milan Cathedral should be situated, 1810. Trieste is probably the city on the sea which appears in the background.

\section{CONCLUSIONS}

The composition method employed can be used as an instrument suitable for anticipating the result in an initial phase of the design process. The simulation of a reference work in the designated place, for example by Moneo or Gehry, facilitates the making of appropriate corrections at this preliminary stage.

Generally speaking, immediate suggestions can be found in critical situations in this way. For example, one case is the Venice railway station building which abuts on the Grand Canal, a building that is the fruit of design compromises because of which the three-dimensionality, as part of a harmonious complex composition of volumes arranged to compose the urban fabric, cannot be read. The substitution by other existing buildings elsewhere that respond to the requirements considered indispensable in the particular context facilitates the development of considerations useful in unravelling the thinking behind the design approach. The head office of the publisher Mondadori in the Milan suburb of Segrate by Oscar Niemeyer seems to be particularly appropriate in this sense.

This experience began with the study of several designs in which Karl Friedrich Schinkel assembled architectures and built places. Luciano Semerani (1982) has observed that his love of ancient Greece brought Schinkel to favour the topological relationship between the objects, "which he placed to constitute a minute face-to-face dialogue with great correlations with the urban structure".

The theme of the new life in Venice, including architecture, is fundamental in breaking the continuous decay of the city which has now almost exclusively become a tourist destination without any rules.

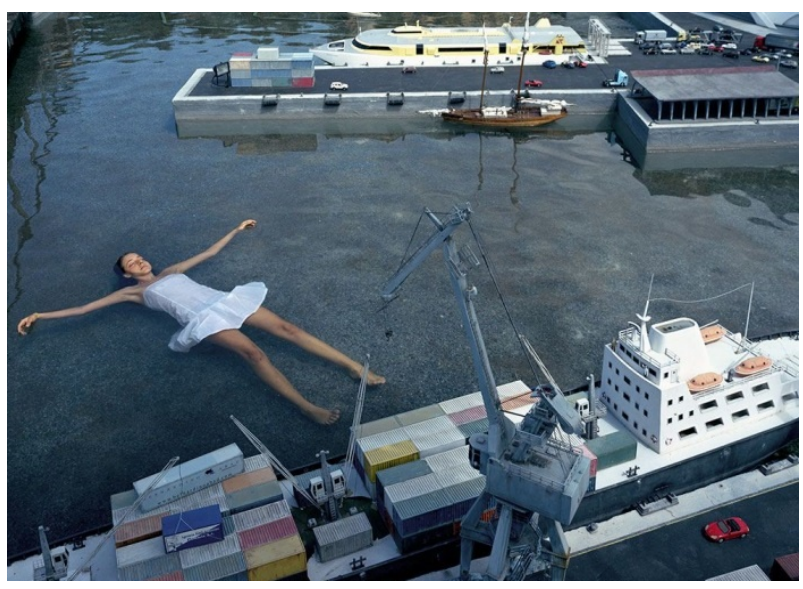

Figure 14. Julia Fullerton-Batten, Floating in Harbour, 2005. The work, which offers a comparison between a water context and a human presence at a different scale, is also offered here as a metaphor for the fate of Venice.

\section{REFERENCES}

Berlage, H. P. (1934) Het Wezen der Bouwkunnst en haar geschiedenis (aesthetique beschowingen), De Erven F. Bohn N.V., Harlem.

Contessi, G. (1985) Architetti-pittori e pittori-architetti. $\mathrm{Da}$ Giotto all'età contemporanea. Edizioni Dedalo, Bari.

Le Corbusier (1979, first edition 1930) Prologo americano, in F. Tentori (Ed.). Precisazioni sullo stato attuale dell'architettura e dell'urbanistica. Rome-Bari, Laterza, 19.

Loos, A. (1992, first edition 1910) Architettura, in Parole nel vuoto, Adelphi, Milan, 255.

Quatremère de Quincy, A. (1832) Immaginazione, in Teyssot, G., Farinati, V. (eds., 1985) Quatremère de Quincy. Dizionario storico di architettura. Marsilio Editore, Venice.

Rossi, A. (1975) Scritti scelti sull'architettura e la città 1956-1972. Clup, Milan.

Rossi, A. (2008) quoted in Celant, G. (ed.) Aldo Rossi. Disegni. Skira editore, Milan, 195.

Semerani, L. (1982) La scuola di Venezia, in Progetti per la città veneta 1926-1981. Neri Pozza Editore, Vicenza, 17.

Sestieri, G. (2015) // Capriccio Architettonico in Italia nel XVII e XVIII secolo. Etgraphiae editoriale, Rome. 